УДК 94(477.6)"1943/1950"

DOI 10.31.65/2520-6966-2020-13i-99-66-78

\title{
О. О. Титаренко
}

кандидат історичних наук, доцент кафедри соціально-гуманітарних дисциплін Донецького юридичного інституту МВС України (м. Кривий Ріг)

e-mail: tytarenko.ok@ukr.net

\section{Жіночий досвід відбудови вугільної промисловості Донбасу в повоєнний період}

У статті охарактеризовано особливості формування жіночого профресійного та особистого досвіду відбудови шахт Донбасу в повоєнний період. Визначено специфріку мобілізаційної кампанії на відбудовчі роботи, висвітлені мотиви, якими керувалися жінки, освоюючи чоловічі просресії. Проаналізовано вплив пропаганди та системи "соціалістичного змагання" як чинників залучення на роботу та підвищення продуктивності праці. Висвітлено умови праці на шахтах, особливості соціальної адаптації, реалізації жінками різних рольових статусів на роботі та в побуті.

Ключові слова: вудільна промисловість, Донбас, повоєнна відбудова, пропаганда, трудова мобілізація, жіноча зайнятість, гендерна політика, адаптація.

Період Другої світової війни та перші повоєнні роки стали часом докорінної трансформації радянського суспільства. Досвід війни, нацистської окупації, повоєнної відбудови мав регіональну специфіку, він по-різному проявився у різноманітних соціальних, професійних, вікових, гендерних групах. Не був винятком і Донбас. Під час характеристики процесів, які відбувалися у базовій сфері промисловості регіону - вуглевидобувній - в середині - другій половині 40-х років, радянська історіографрія традиційно зосереджувала увагу на успіхах відбудови виробничої інфраструктури [11; 15; 20], залишаючи поза належною увагою питання, пов'язані із соціальними, демографічними процесами, специфікою гендерних ролей під час відбудови. Вже в 1990-2000 роки зазначені аспекти стали об'єктом досліджень І. Єсипа [9], М. Герасимової [5], Н. Шипік [26], Т. Пентер [29], В. Сусликова та Д. Титаренка [22], І. Татарінова [23], К. Кузіної [16] та ін. Водночас на більш детальну розробку заслуговують питання, пов'язані із жіночим досвідом відбудови вугільної промисловості Донбасу. Це, зокрема, передбачає виконання наступних завдань: охарактеризувати особливості мобілізації жінок на відбудову вугільної промисловості, значення пропагандистських кампаній у стимулюванні жіночої трудової активності; проаналізувати роль і місце держави у створенні умов для адаптації жінок у повоєнному суспільстві; визначити 
способи реалізації соціальних ролей "матері", "жінки", "робітниці", а також вплив жінок на формування нової соціальної системи.

Одразу ж після визволення східних регіонів України у другій половині 1943 р. нагальною потребою стало масове поповнення, мобілізація трудових ресурсів. Основною причиною цього була критично мала кількість чоловічого населення у промисловості через мобілізацію його до армії. Ці потреби в робочій силі мали бути частково вирішені за рахунок мобілізації жінок, підлітків та військовополонених [22, с. 92].

Держава змушена була підтримати та заохотити залучення жінок до важкої фрізичної праці. Участь жінки в процесі відбудови та модернізації радянської економіки, в тому числі виконання нею ролей, не сумісних із ії фрізичними можливостями, явно була продиктована не потребами ії емансипації. На порядку денному стояли набагато прагматичніші чинники: швидке відновлення важкої промисловості, використання дешевої робочої сили.

Уже на першому етапі відбудови у транспорт і промисловість східних регіонів України було мобілізовано близько $1 \mathrm{mлн} \mathrm{осіб,}$ здебільшого жінок із села. До повернення чоловіків з Червоної армії жінки складали переважаючу кількість промислових робітників. Станом на 1 січня 1945 р. у машинобудуванні жінки складали 52,9 \%, у вугільній промисловості - 45,6 \%, у чорній металургії - 43,2 \% усіх працівників, переважну більшість у хімічній, текстильній, легкій та харчовій промисловості. Гострота ситуації зумовила відступ від чинних раніше у сфрері трудового законодавства приписів і стандартів: так, у вугільній промисловості почали застосовувати раніше заборонену працю жінок під землею. Станом на 1944 рік під землею працювало 40 \% жінок, зайнятих у вугільній промисловості [13, с. 153-154], на поверхні їхня кількість сягала 55,9 \% [11, с. 248].

Масовий характер використання жіночої праці призводив до того, що жінки - переважно некваліфікована частка робітників - працювали як чорнороби, підручні, вантажники. Механізація в ході здійснення відбудовчих робіт, особливо на розбиранні завалів та розчищенні майданчиків, копанні траншей та перенесенні будівельних матеріалів тощо, була вкрай низькою. Ручна праця, а саме вона переважала на відбудовчих роботах, до певної міри нівелювала гендерні відмінності. У той же час недостатній рівень кваліфікації цієї робочої сили, передусім жінок, мав наслідком затримки у проведенні будівельних відновлювальних робіт на підприємствах Донбасу [8, арк. 40-41].

Потужним чинником залучення на відновлювальні роботи на вугільні підприємства стала пропаганда. Вже невдовзі після визволення 
регіону влада звернулася до жінок і дівчат із закликом взяти участь у відбудові шахт Донбасу і таким чином підтримати наступ Червоної армії [29, с. 344]. Характерною особливістю пропаганди повоєнного періоду була глорифікація шахтарської праці, прикрашення реальності та замовчування інформації щодо умов роботи на вугільних підприємствах. Пропаганда розглядала труднощі як тимчасове явище, малювала романтизований образ шахтарської праці та щасливого майбутнього, зображувала абсолютно нові життєві перспективи. Свідченням визнання на локальному рівні особливого статусу шахтарської професії, створення її певного культу стало введення в 1947 році в офріційний календар свята "День шахтаря", який мав відзначатися в останню неділю серпня [24, с. 66].

Залучення до роботи на вугільних підприємствах часто-густо відбувалося шляхом примусових мобілізацій, передусім сільської молоді. Важкі умови праці, невирішеність цілого комплексу питань соціальнопобутового плану, байдужість керівництва до потреб робітників мали наслідком дезертирство, яке набувало значних масштабів. Особливо масовим було дезертирство саме у вугільній промисловості [11, с. 251]. Виробнича необхідність, доведена до абсолюту, доволі часто мала наслідком ситуації, коли на важкі фізичні роботи з інших робочих ділянок примусово спрямовувалися жінки без необхідної професійної кваліфікації. У важкій промисловості жінкам доводилося швидко оволодівати "чоловічими" спеціальностями: забійників, кріпильників, бутчиць, слюсарів, електрозварників тощо [20, с. 165]. Слід зазначити, що схожа ситуація спостерігалася і в інших промислових центрах Сходу України, зокрема у Кривбасі, Запорізькій області.

Професія шахтарки була відносно "молодою" за віком. Так, станом на 1947 р. у вугільній галузі Сталінської області працювало 16, 3 \% жінок у віці від 16 до 20 років; 27 \% - від 20 до 25 років; 29,6 \% від 26 до 35 років; 22,3 \% - від 36 до 49 років. Таким чином 72,9\% робітниць на шахті були дівчата та молоді жінки у віці від 16 до 35 років. До початку 1950-х рр. помітною стала така тенденція: кількість робітниць від 16 до 20 років знизилась до $10 \%$ (станом на 1951 р.), що свідчило про зменшення припливу дівчат на шахти [16, с. 59].

Певну роль у притоку жінок, зокрема у важку промисловість, відіграла оплата праці. Так, якщо в 1950 р. середньомісячна заробітна плата становила 640,2 крб, то заробітна платня у вугільній промисловості була майже вдвічі більше - 1200 крб У підземних робітників основних професій вона доходила до 3-4 тис. крб і більше. I надалі ця тенденція зберігалась. Різниці в оплаті праці у вугільний промисловості між чоловіками та жінками не було [16, с. 59]. В цілому 
заробітна плата робітників в інших галузях промисловості була значно нижчою, ніж у важкій промисловості, зокрема на шахтах [18, с. 190].

Саме зарплата, за умови відсутності у багатьох жінок загиблих на війні чоловіків, необхідності утримувати родину, була важливим стимулом йти працювати на шахти. У той же час високі ціни на продукти харчування, постійний дефіцит необхідних товарів у перші повоєнні роки нівелювали значення заробітної плати.

Важкі умови праці на промислових підприємствах, незадовільні побутові умови, голод спричинили плинність кадрів, особливо жінок. Оскільки основний акцент було зроблено не на техніку, а на використання людського ресурсу, це мало наслідком актуалізацію ідеї "соціалістичного змагання". Ринкові механізми стимулювання праці мали бути компенсовані ідеєю "героїчної праці" на підприємствах. Вважалося, що наслідком стане підвищення продуктивності праці, поліпшення її організації.

Профспілки, що організовували "соціалістичне змагання", намагалися залучити до нього якнайбільше робітників та службовців, створити обстановку звитяжної праці на підприємствах. Ініціатива окремих людей і цілих колективів відіграла важливу роль у відновленні промислових підприємств та шахт. Ентузіазм, який у багатьох був щирим адже часто люди керувалися бажанням якнайшвидше відновити зруйновані міста, села, шахти, підприємства, - дав швидкі результати.

Показовою стала ініціатива колгоспниць Олександрівського району Сталінської області Марії і Надії Клименко, Ольги і Галини Копейко, Катерини Щербат. Жінки звернулися до всіх колгоспників, новоприбулих на підприємства вугільної промисловості, із закликом самозакріпитися для постійної роботи в Донбасі. Зазначений крок був підтриманий партійними органами, які намагалися шляхом поширення відповідної інфрормації вирішити проблему трудових ресурсів регіону [9, с. 74-75].

Важливою формою обміну набутим досвідом, а також пропаганди були зльоти представників шахтарських професій. Так, 11 грудня 1943 р. у Горлівці відбувся зліт жінок-шахтарок, які закликали радянських жінок йти працювати в шахтні забої. Приклади вчорашніх домогосподарок, колгоспниць, вчительок, які ніколи не тримали у руках шахтарських обушків, за короткий термін оволоділи шахтарськими профресіями і виконували норму на 200 \%, мали стати гідними наслідування [4, с. 145]. Деякі з них набули канонічного характеру в пропаганді: широко відомим став рекорд, встановлений 30 січня 1944 р. шахтаркою м. Горлівки Марією Гришутіною. За зміну вона нарубала 40 тонн вугілля, виконавши норму на 1145 \% [15]. У 1944 р. Віра Оракулова встановила новий рекорд, нарубавши за зміну 71 тонну вугілля 
і виконавши завдання на 1400 \%. Щоправда, партійні органи та пропагандистський апарат не завжди оперативно та адекватно реагували на тогочасні виклики. Так, плануючи в 1946 р."... з метою широкої популяризації передового досвіду роботи кращих стахановців Сталінської області - новаторів промисловості, транспорту та сільського господарства..." видання збірника виробничих нарисів, бюро обкому КП (б)У не навело жодного прізвища жінки, зайнятої на виробництві, зокрема на шахтах. Дві жінки, трудові здобутки яких планувалося висвітлити у запланованій книзі, були колгоспницями [6, арк. 50].

Більш складним, з точки зору демонстрації успішної спільної праці, було досягнення високих показників у рамках виробничих колективів - бригад. Тим не менш колективи, які систематично показували високий результат, не були рідкістю. Так, наприклад, жіночі бригади Марії Медвецької і Тетяни Іванової тресту "Будьоніввугілля" постійно виконували змінне завдання на 150-170\%. Запорукою цього була робота всіх членів колективу, які з плином часу набували професійного досвіду. Показово процес професійного становлення описала забійниця шахти ім. Калініна Ніна Кузьменко: "Спочатку рубала по півтонни в день, потім 2-3 тонни, а в останні дні даю по 6 тонн, вдвічі більше перекриваючи норму... " [21].

В цілому ж система "соціалістичного змагання", за умов відсутності комплексного підходу керівництва до вирішення як виробничих, так і соціальних питань, а також необхідного матеріального стимулювання, могла забезпечувати необхідний економічний ефект впродовж відносно короткого часу. Загалом продуктивність у вугільній промисловості залишалася достатньо низькою [2, с. 30-33].

Робота на промислових підприємствах була пов'язана із важкими фрізичними навантаженнями, до яких суто фрізіологічно жінки пристосовані не були. Показовою $є$ характеристика умов, з якими стикалися на виробництві жінки, досить часто підлітки, в автобіографічних наративах працівниць шахт: "зміна продовжувалася часто по 12 годин і більше", "стояла по коліна у воді", "переганяла вагонетки з вугіллям" [27, с. 16-19]. Надзвичайно високим був ризик травм, особливо серед дівчат і жінок, мобілізованих у сільських регіонах України, Росії та інших союзних республік.

За умов повоєнної розрухи та голоду у монопромислових містах та селищах Сходу України робота на шахтах чи заводах часто була єдиним засобом забезпечення себе та родини найважливішим продовольством. У багатьох випадках дівчата-підлітки самі приписували собі кілька років, щоб мати можливість влаштуватися на роботу. Показовою є ситуація на шахті "6 Капітальна" тресту "Сталінвугілля". 
Так, серед тих, хто працював на шахті, наймолодшими були Крамарєва Ольга, Бельських Ніна, Бойко Валентина, Федорова Лідія. Всі вони були 1930 року народження і вже в п'ятнадцяти-шістнадцятирічному віці прийшли працювати на підприємство.

Типовими в плані зображення реалій роботи, побуту, продовольчого забезпечення на той час $є$ спогади шахтарки Крамарєвої: "... Час був голодний, а на шахті видавали картки на харчування й щодня 700 грамів хліба тим, хто був на поверхні, а підземникам 1 кг. 200 гр. Одяг знаходили самі собі. Шили рукавиці, без них ніяк не можна, особливо взимку, бо руки примерзали до металу. Калоші, які видавали, були дуже великими. Доводилося задники підрізати і підшивати, а щоб не падали, прив'язувати мотузками. Баню побудували не відразу, тому милися вдома, в кориті, по черзі" [27, с. 18]. Загальна динаміка відбудовчого процесу, в ході якого, хоч і повільно, робочі місця із важкими умовами праці займалися чоловіками, зміна сімейного статусу мали наслідком зміни в робочих долях жінок. Так, більшість із них, відпрацювавши на шахті від 5 до 8 років, після народження дітей на підприємство не повернулися або виконували наземну роботу.

Хронічною проблемою був брак відповідного спецодягу та обладнання. На більшості шахт робітники не були забезпечені спецодягом, а той, який видавався, не відповідав нормам. Формально рівень забезпечення робітників одягом становив $100 \%$, а фактично, 3 огляду на його низьку якість, не перевищував 50-60 \% [22, с. 456]. Це безпосередньо відбивалося і на продуктивності праці.

Ситуація, що склалася, знайшла відображення у постанові ЦК ВКП(б) "Про стан партійно-політичної роботи на вугільних шахтах Донбасу" від 28 лютого 1948 р. У ній було звернуто увагу на причину великої плинності кадрів - умови праці та життя прибулих, намічено низку відповідних заходів, внесено зміни до умов оргнаборів та мобілізацій молоді до шкіл ФЗН та ремісничих училищ [12, с. 177-178]. I хоча соціально-побутові умови не могли швидко змінитися, проте суттєво збільшилася кількість молоді, яка прибувала за призовами до ФЗН та ремісничих училищ, а також кількість дорослих за оргнаборами.

Робота на підприємствах та в установах була не єдиною сферою робочої активності жінок. Не менш важливим її елементом була діяльність, пов'язана із веденням хатнього господарства, виконанням після завершення робочого дня, а також перед його початком, певної кількості щоденних завдань. Йдеться про справи, пов'язані із приготуванням їжі, закупівлею продуктів та споживчих товарів, пранням та ремонтом одягу, прибиранням помешкань, доглядом за дітьми, людьми похилого віку, хворими, роботою на присадибних ділянках і 
городах, доглядом за домашньою худобою. Тобто протягом ще кількох годин кожного дня жінки мали виконувати певні види роботи. Ця "робота після роботи" мала дві важливі ознаки, які до певної міри впливали на сприйняття жінки. Перша - це те, що така робота була неоплачуваною і не давала безпосереднього заробітку. Друга риса полягала в тому, що значну частку цієї рутинної, ідентичної у більшості сімей роботи виконували люди однієї статі - жінки.

Виснажені фрізично та емоційно жінки потребували підвищеної уваги з боку системи охорони здоров'я. Відразу після визволення на території східних областей України було відновлено роботу лікарень та фрельдшерських пунктів. В цілому протягом другої половини 40-х початку 50-х рр. медичне забезпечення населення міст поступово покращувалося, знижувався рівень загальної захворюваності, проте традиційно високим залишався рівень профресійних захворювань та виробничого травматизму. Передусім це стосувалося працівників важкої промисловості. Багато необхідних ліків були постійним дефіцитом, бракувало кваліфрікованого лікарського персоналу.

Жінки, зайняті на виробництві і, як правило, мобілізовані за системою оргнаборів, проживали в непристосованих для життя умовах (бараках, землянках), часто без належної медичної допомоги. Катастрофрічно погані умови проживання, нерегулярне продовольче постачання, байдужість керівництва підприємств призводили до ситуацій, коли серед робітниць мали місце смертні випадки [22, с. 93, 350]. В основі цих явищ лежав також і залишковий принцип фрінансування охорони здоров'я, слабка матеріальна база лікувальних установ, недостатнє забезпечення житловими умовами медпрацівників, що породжувало плинність кадрів [3, с. 14].

Серйозною проблемою, що була пов'язана із високим рівнем смертності жінок, зокрема у промислових центрах, були підпільні аборти. Більшість молодих сімей не могли дозволити собі народжувати більше однієї дитини через низьку заробітну плату та відсутність житла. Кількість штучних переривань вагітності, незважаючи на кримінальнуну відповідальність, залишалася високою [17, с. 70-71].

У цьому контексті роз'яснення потребує сімейна державна політика, яку регулював виданий 1944 р. Указ Президії ВР СРСР "Про збільшення державної допомоги вагітним жінкам, багатодітним та одиноким матерям, посилення охорони материнства та дитинства..." Поклавши на жінок роль репродуктивної сили і трудового ресурсу, радянська влада фактично здійснила дееротизацію жінок. Радянські жінки були зобов'язані відтворювати нових членів суспільства, яких держава виховувала за своїми ідеологічними штампами [25, с. 74]. 
Материнство при цьому розглядалося як соціальне зобов'язання жінки. Народження дітей перестало бути власною справою подружжя, його звели в ранг громадянського обов'язку. При цьому держава наголошувала на відповідальності родин за виховання дітей в комуністичному (за визначенням О. Некріча та М. Геллера - "конформістському") дусі [28, с. 155]. Охорона материнства і дитинства стали головним державним завданням. 3 часом воно трансформувалося, жінки мали поєднувати материнство з участю у виробництві та суспільно корисній діяльності.

Було б помилковим недооцінювати роль громадських ініціатив, які, за умов відсутності або браку державних, відігравали певну роль у налагодженні функціонування соціальної сфрери, поліпшенні побуту робітників. Провідну роль у них відігравали жінки. Влада, вбачаючи в цьому потенційну користь, схвально реагувала на них. Так, позитивно оцінюючи роботу жінок - громадських активісток щодо поліпшення побутових умов шахтарів у повоєнні роки, міністр вугільної промисловості О. Засядько висунув вимогу поширювати їхній досвід із шахтоуправління Донбасу [7, арк. 130-131].

Широке застосування жіночої праці стало однією із найважливіших складових відбудови вугільної промисловості Донбасу. Ключовими чинниками, що використовувалися для залучення на роботу, стала активна пропаганда, продовольче постачання та порівняно висока заробітна плата, а також застосування насильницьких методів під час мобілізацій на підприємства вугільної промисловості. Робота на шахтах була пов'язана із значними фізичними навантаженнями, які не враховували жіночої фрізіології і відбивалися на стані здоров'я. Серйозними проблемами, із якими стикалися жінки, був брак спецодягу, досить часто недостатнє продовольче забезпечення, високий рівень травматизму, незадовільний рівень медичного обслуговування. Складнощі участі жінок у повоєнній відбудові були пов'язані із необхідністю, окрім роботи на підприємствах, участі у веденні господарства та вихованні дітей. Зазначена ситуація, демонструючи наявність низки соціальних ролей в зайнятих на виробництві жінок, в той же час обмежувала можливості їхнього повноцінного самовираження, дозвілля та консервувала стан невирішеності соціальних проблем у повоєнному радянському суспільстві.

\section{Література}

1. Алфьоров М. А. Міграційні процеси та їх вплив на соціально-економічний розвиток Донбасу (1939-1959рр.). Донецьк: Український культурологічний центр, Донецьке відділення Наукового товариства ім. Шевченка, 2008. 192 с. 
2. Баран В. К., Даниленко В. М. Україна в умовах системної кризи (1946-1980-і рр.). Київ: Альтернативи, 1999. 304 с.

3. Вовк В. М. Побут та дозвілля міського населення України в 50-х 80-х рр. XX століття: автореф. дис. ... канд. іст. наук: 07.00.01; Нац пед. ун-т ім. М. П. Драгоманова. Київ, 2007. 20 с.

4. Водотика Т., Кузіна К. Люди в мономістах Донбасу: комірці та роби. Регіональна історія України: зб. наук. ст. Київ: Інститут історії України НАН України, 2017. Вип. 11. С. 133-150.

5. Герасимова М. С. Історичні умови формування та правила організації повсякденного життя в Донбасі в 1945-1953 рр. Нові сторінки історії Донбасу: зб. ст. Донецьк: ДонНУ, 2006. Кн. 12. С. 116-128.

6. Державний архів Донецької області (далі - ДАДО). Ф. 326. Оп. 4. Спр. 131.

7. ДАДО. Ф. Р-2895. Оп. 1. Спр. 857.

8. ДАДО. Ф. Р-2895. Оп. 1. Спр. 45.

9. Добров П. В., Есип И. М. Трудовая деятельность женщин Донбасса в годы Великой Отечественной войны (1941-1945). Донецк: ООО Фирма "Друк-Инфо", 2000. 240 с.

10. Донецкая область в годы Великой Отечественной войны (19411945 гг.): сб. докум. и матер. / редкол.: Е. Д. Клерфон (отв. ред.) и др.; сост.: Лебедев В. И. (отв. сост.) и др. Донецк: Донбас, 1980. 311 с.

11. Донетчина в годы Великой Отечественной войны 1941-1945. Известные и неизвестные страницы истории. Донецк: АОЗТ "Изд-во "Донетчина", 2008. 432 с.

12. Жбанова К. Організований набір робітників у відбудові Донбасу (1943-1950рр.). Сіверянський літопис. 2015. № 1 (121). С. 174-181.

13. Жіночі студії в Україні: жінка в історії та сьогодні: монографрія / за заг. ред. Л. О. Смоляр. Одеса: Астропринт, 1999. 440 с.

14. История рабочих Донбасса: в 2 т. Київ: Наукова думка, 1981. Т. 2.: Рабочие Донбасса в период завершения строительства социализма и постепенного перехода к коммунизму / сост. А. В. Лихолат, Л. А. Беспалова, В. Ф. Близнюк и др. 431 с.

15. Кочегарка. Горловка. 1944. 1 февр.

16. Кузіна К. Жінки-шахтарки: до питання використання жіночої праці у вугільній промисловості Донбасу у другій половині 1940-х-1950-і рр. Нові сторінки історії Донбасу: зб. ст. Донецьк: ДонНУ, 2013. Кн. 22. С. 56-65.

17. Лебина Н. Мужчина и женщина. Тело, мода, культура. Москва: Новое литературное обозрение, 2014. 208 с.

18. Саржан А. А. Повсякденне життя населення Донбасу у повоєнні роки. Нові сторінки історії Донбасу: зб. ст. Донецьк: ДонНУ, 2013. Кн. 22. C. $188-196$.

19. Сидоренко П. А. Восстановление и дальнейшее развитие угольной промышленности Донбасса в послевоенный период (1946-1950 гг.). Годы героического труда: сб. ст. / сост. Ф. Р. Зимоглядов. Сталино: Книжное издво "Сталино-Донбасс", 1961. С. 77-99. 
20. Смольніцька М. Жінка в радянському суспільстві: офріційний образ і реальна практика. Україна $X X$ століття: культура, ідеологія, політика. Київ, 2011. Вип. 16. С. 162-174.

21. Социалистический Донбасс. Сталино. 1943. 11 дек.

22. Сусликов В. Є., Титаренко Д. М. Горлівка в період Великої вітчизняної війни та перші повоєнні роки (1941-1950): історичний нарис та джерела. Донецьк: Норд-Прес, 2010. 505 с.

23. Татарінов І. Є. Матеріально-побутові умови життя працівників важкої промисловості УРСР у 1944-1956 рр.: автореф. дис. ... канд. іст. наук: 07.00.01 / Східноукр. нац. ун-т ім. В. Даля. Луганськ, 2010. 19 с.

24. Титаренко О. Ю. Культурне життя на Донбасі у відбудовчий період (1943-1953 рр.): дис. ... канд. іст. наук: 07.00.01 / Запорізький національний ун-т. Запоріжжя, 2017. 288 с.

25. Фатхутдінова І. Роль української жінки в сім"ї та суспільстві. Науковий вісник. Серія "Філософрія". Харків: ХНПУ, 2015. Вип. 45 (ч. І). С. 62-84.

26. Шипік Н. Ф. Соціально-демографічні процеси в Донбасі в 19431955 рр.: дис. ... канд. іст. наук: 07.00.01 / Донецький національний ун-т. Донецьк, 2005. 250 с.

27. Шуманська М. В. Жінки-шахтарки Донбасу і селища "6 Капітальна" в повоєнній відбудові 1943-1950рр.: науково-дослідницька робота. Секція "Історичне краєзнавство" Донецького територіального відділення МАН України. Донецьк, 2012. Рукопис. (Архів Донецького обласного центру туризму і краєзнавства учнівської молоді).

28. Heller M., Nekrich A. Geschichte der Sowjetunion. Zweiter Band. Königstein /Ts. Athenäum Verlag GmbH, 1982. 455 S.

29. Penter T. Kohle für Stalin und Hitler. Arbeiten und Leben im Donbass 1929 bis 1953. Essen: Klartext Verlag, 2010. 467 s.

\section{References}

1. Alf'orov, M. A. (2008). Mihratsiini protsesy ta yikh vplyv na sotsial'noekonomichnyi rozvytok Donbasu (1939-1959 rr.) [Migration processes and their impact on the socio-economic development of Donbass (1939-1959)]. Donets'k [in Ukrainian].

2. Baran, V. K., \& Danylenko, V. M. (1999). Ukraina v umovakh systemnoi kryzy (1946-1980-i rr.) [Ukraine in the conditions of system crisis (1946-1980's)]. Kyiv [in Ukrainian].

3. Derzhavnyi arkhiv Donetskoi oblasti (DADO) [State Archives of the Donetsk oblast, Donets'k]. F. 326. Op. 4. Spr. 131.

4. DADO. F. R-2895. Op. 1. Spr. 857.

5. DADO. F. R-2895. Op. 1. Spr. 45.

6. Dobrov P. V., \& Yesyp I. M. (2000). Trudovaya deyatel'nost' zhenshchin Donbassa $v$ gody Velikoy Otechestvennoy voyny (1941-1945) [The female labor force participation in Donbass during the Great Patriotic War (1941-1945)]. Donetsk [in Russian].

7. Fatkhutdinova, I. (2015). Rol' ukrains'koi zhinky v sim'i ta suspil'stvi [The Role of the Ukrainian woman in the family and society] Naukovyy visnyk Scientific Bulletin. Issue 45, 62- 84. Kharkiv: KhNPU [in Ukrainian]. 
8. Heller M., Nekrich A. (1982). Geschichte der Sowjetunion. Band 2. Königstein: Ts. Athenäum Verlag $\mathrm{GmbH}$.

9. Herasymova, M. S. (2006). Istorychni umovy formuvannia ta pravyla orhanizatsii povsiakdennoho zhyttia v Donbasi v 1945-1953 rr. [Historical conditions of formation and rules of organization of daily life in Donbass in 19451953] Novi storinky istorii Donbasu - New pages in the history of Donbass, Vol. 12, 116-128 [in Ukrainian].

10. Klerfon, Ye. D. (Eds.) (1980). Donetskaya oblast' v gody Velikoy Otechestvennoy voyny (1941-1945 gg.) [Donetsk Oblast' during the Great Patriotic War (1941-1945)]. Donetsk: Donbas [in Russian].

11. Kochegarka [Stokehold]. (Gorlovka). 1944. 1 fevr. [in Russian].

12. Kuzina, K. (2013). Zhinky-shakhtarky: do pytannia vykorystannia zhinochoi pratsi u vuhil'nii promyslovosti Donbasu u druhii polovyni 1940-kh - 1950-i rr. [Female miners: to the question of the female labor force participation in the Donbass coal industry in the second half of the 1940's - 1950's]. Novi storinky istorii DonbasuNew pages in the history of Donbass, Vol. 22, 56-65. [in Ukrainian].

13. Lebina, N. (2014). Muzhchina i zhenshchina. Telo, moda, kul'tura [Man and woman. Body, fashion, culture. ] Moscow: Novoye literaturnoye obozreniye [in Russian].

14. Likholat, A. V., Bespalova, L. A., \& Bliznyuk, V. F. (1981). Istoriya rabochikh Donbassa [History of Donbass workers]. (Vols. 1-2; Vol. 2). Kiyev: Naukova dumka [in Russian].

15. Penter, T. (2010). Kohle für Stalin und Hitler. Arbeiten und Leben im Donbass 1929 bis 1953. Essen: Klartext Verlag.

16. Sarzhan, A. A. (2013). Povsiakdenne zhyttia naselennia Donbasu u povoienni roky [Everyday life of the population in Donbass in the postwar years]. Novi storinky istorii Donbasu - New pages in the history of Donbass, Vol. 22, 188196 [in Ukrainian].

17. Shumans'ka, M. V. (2012). Zhinky-shakhtarky Donbasu i selyshcha "6 Kapital'na" v povoyennii vidbudovi 1943-1950 rr. [Female miners of Donbass and settlement "6 Kapital'na" in the postwar reconstruction 1943-1950]. Research work. Manuscript]. Donets'k: Donetsk oblast center of tourism and regional studies for student youth [in Ukrainian].

18. Shypik, N. F. (2005). Sotsial'no-demohrafichni protsesy v Donbasi v 1943-1955 rr. [Socio-demographic processes in Donbass in the 1943-1955]. Candidate's thesis. Donets'k [in Ukrainian].

19. Sidorenko, P. A. (1961). Vosstanovleniye i dal'neyshyeye razvitiye ugol'noy promyshlennosti Donbassa v poslevoyennyy period (1946-1950 gg.) [Restoration and further development of the coal industry in Donbass in the postwar period (1946-1950)]. Gody geroicheskogo truda - Years of the heroic work. Stalino: Knizhnoye izdatel'stvo Stalino-Donbass, 77-99 [in Russian].

20. Smoliar, L. O. (Eds.). (1999). Zhinochi studii v Ukraini: zhinka v istorii ta s'ohodni [Women's studies in Ukraine: a woman in history and modern]. Odesa: Astroprynt [in Ukrainian].

21. Smol'nits'ka, M. (2011). Zhinka v radians'komu suspil'stvi: ofitsiinyi obraz i real'na praktyka [Woman in Soviet society: official image and real practice]. 
Ukraina XX stolittia: kul'tura, ideolohiia, polityka - Ukraine of the twentieth century: culture, ideology, politics, Vol. 16, 162 - 174 [in Ukrainian].

22. Sotsialisticheskiy Donbass [Socialist Donbass]. (Stalino). 1943. 11 dek.

23. Suslykov V. Ye., \& Tytarenko D. M. (2010). Horlivka v period Velykoi Vitchyznianoi viiny ta pershi povoienni roky (1941-1950): istorychnyi narys ta dzherela [Gorlovka in the period of Great Patriotic War and the first postwar years (1941-1950): Historical outline and sources]. Donets'k: Nord-Pres [in Ukrainian].

24. Tatarinov, I. Ye. (2010). Material'no-pobutovi umovy zhyttia pratsivnykiv vazhkoi promyslovosti URSR u 1944-1956 rr. [Material living conditions of heavy industry workers of the USSR in 1944-1956]. Extended abstract of candidate's thesis. Luhans'k [in Ukrainian].

25. Tretyak, O. L. (Eds.). (2008). Donetchina v gody Velikoy Otechestvennoy voyny 1941-1945. Izvestnyye $i$ neizvestnyye stranitsy istorii (2008). [Donetsk region during the Great Patriotic War 1941-1945. Known and unknown pages of history]. Donetsk: AOZT "Izdatel'stvo "Donechchyna" [in Russian].

26. Tytarenko, O. Yu. (2017). Kul'turne zhyttya na Donbasi u vidbudovchyy period (1943-1953 rr.) [Cutural life in Donbass in the postwar reconstruction period (1943-1953)]. Candidate's thesis. Zaporizhzhya [in Ukrainian].

27. Vodotyka, T., Kuzina, K. (2017). Liudy v monomistakh Donbasu: komirtsi ta roby [People in monocities of Donbass: white-collars and hard workers] Rehional'na istoriia Ukrainy - Regional history of Ukraine, Issue 11, 133-150 [in Ukrainian].

28. Vovk, V. M. (2007). Pobut ta dozvillia mis'koho naselennia Ukrainy $v$ 50-kh - 80-kh rr. XX stolitti [Life and leisure of the urban population of Ukraine in the 50's - 80's of the XX century]. Extended abstract of candidate's thesis. Kyiv [in Ukrainian].

29. Zhbanova, K. (2015). Orhanizovanyi nabir robitnykiv u vidbudovi Donbasu (1943-1950 rr [An organized mobilization of workers in the reconstruction of Donbass (1943-1950)] Siverians'kyi litopys - Siverians'kyi chronicle, 1(121). 174181 [in Ukrainian].

\section{O. O. Tytarenko}

Candidate of Historical Sciences, Associate Professor, Associate Professor at the Department of Social and Humanitarian Sciences at Donetsk Institute of Law (Kryvyj Rig) e-mail: tytarenko.ok@ukr.net

Female experience in the reconstruction of the coal industry of Donbass in the postwar period

In the article the peculiarities of the female professional and personal experiences in reconstruction of the coal mining in Donbass during the postwar period are described. The female labor force participation in reconstruction was caused by demographic imbalance between women and men as a result of war, by the recognition of the vital importance of heavy industry for state. The specificity of mass mobilization for economic reconstruction is determined, the motivation of females to work in male-dominated fields of industry are highlighted. The influence of propaganda and the system of "socialist competition" as factors, contributing to increasing the labor productivity is analyzed. It is noted that under the 
conditions of unsettled economic and social problems these measures provided the necessary economic effect for a relatively short time. The working conditions in the coal mines are represented. There are some problems, which women, employed in the coal-mining, had: lack of experience, difficult working conditions, traumatic injuries, problems in food supply, poor medical care. The peculiarities of social adaptation and the different role statuses at work and at home are highlighted. According to the state policy the women must combine the family life, in particular motherhood, with work and social activity. The state had supported such social initiatives. The female labor force participation whether voluntary or forced, has become one of the most important factors in the post-war reconstruction of the coal industry in Donbass.

Key words: coal industry, Donbass, post-war reconstruction, propaganda, labor mobilization, female labor force partisipation, gender policy, adaptation. 